\title{
Matrix-isolation and solid state low temperature FT-IR study of 2,3-butanedione (diacetyl)
}

\author{
A. Gómez-Zavaglia ${ }^{\mathrm{a}, \mathrm{b}}$, R. Fausto ${ }^{\mathrm{a}, *}$ \\ ${ }^{a}$ Department of Chemistry, University of Coimbra, Coimbra P-3004-535, Portugal \\ ${ }^{\mathrm{b}}$ Facultad de Farmacia y Bioquímica, Universidad de Buenos Aires, Buenos Aires RA-1113, Argentina \\ Received 5 May 2003; accepted 20 June 2003 \\ Dedicated to Professor Bernhard Scrader
}

\begin{abstract}
2,3-Butanedione (diacetyl) was studied by matrix-isolation and low temperature solid state FT-IR spectroscopy, supported by molecular orbital calculations undertaken at the DFT(B3LYP) and MP2 levels of theory with the 6-311++G(d,p) basis set. Both in the crystalline phase and in the matrices, the compound exists in the $C_{2 h}$ symmetry trans conformation $(\mathrm{O}=\mathrm{C}-\mathrm{C}=\mathrm{O}$ dihedral angle of $180^{\circ}$ ). This form corresponds to the single conformational state predicted by the theoretical calculations for the compound in vacuum. However, in the low temperature amorphous state, obtained by fast deposition of the vapour of the compound onto a suitable cold $(9 \mathrm{~K})$ substrate, as well as in the liquid and gaseous phases, spectroscopic features are observed that can only be explained by assuming that conformations without an inversion centre $\left(C_{2}\right.$ symmetry) do also contribute to the spectra. These results are in agreement with the experimental evidence that diacetyl has a permanent dipole moment (ca.1 Debye) in the vapour phase at room temperature and are here explained taking into consideration the influence of the low frequency large amplitude torsional vibration around the central $\mathrm{C}-\mathrm{C}$ bond on the molecular properties.
\end{abstract}

(C) 2003 Elsevier B.V. All rights reserved.

Keywords: Diacetyl; Matrix-isolation FT-IR; Density functional theory calculations; Molecular structure; Dipole moment

\section{Introduction}

2,3-butanedione (most currently known as diacetyl) is a naturally occurring chemical in bay and other oils, beer, butter, coffee, vinegar, and other food products [1]. It can also be obtained from cultures of Lactococcus lactis subsp. lactis biovar diacetylactis, being used as an artificial flavouring which adds the characteristic flavour most commonly associated with butter, cream and butterscotch [1-5]. In spite of its

\footnotetext{
* Corresponding author.

E-mail address: rfausto@ci.uc.pt (R. Fausto).
}

practical uses in the food industry, exposure to relatively large quantities of diacetyl might be harmful to the skin, eye, mucous membrane and respiratory system $[6,7]$.

Diacetyl has been extensively studied in the past regarding its electronic excited states properties. In particular, since diacetyl has easily accessible low energy singlet and triplet states, its photoluminescence (both fluorescence and phosphorescence) spectra have been the subject of many detailed studies [8-15]. At room temperature, diacetyl is liquid, but it solidifies at ca. $-2{ }^{\circ} \mathrm{C}$. Its crystal structure was already determined by X-ray crystallography [16], 
both at -12 and $-100{ }^{\circ} \mathrm{C}$. The crystals were found to be monoclinic, space group $P 2_{1} / n$, with two molecules per unit cell. Molecules in the crystal are in the $C_{2 h}$ symmetry trans conformation, with the $\mathrm{O}=\mathrm{C}-\mathrm{C}=\mathrm{O}$ intercarbonyl dihedral angle equal to $180^{\circ}$ [16] (Fig. 1).

In the gaseous phase, the structure of diacetyl has been investigated by electron diffraction [17-19] at different temperatures. In all those studies the presence of a single conformer (trans) in the gas phase was also stated. ${ }^{17} \mathrm{O}-\mathrm{NMR}$ measurements of the compound in dry acetonitrile solution at $70{ }^{\circ} \mathrm{C}$ [20] enabled to reach essentially the same conclusion, but with the important difference that the intercarbonyl dihedral angle was determined as being ca. $158^{\circ}$. This result contradicts the accumulated experimental evidence from vibrational spectroscopic (both IR and Raman) studies of the compound in several experimental conditions [21-25] that assumed observation of the mutual exclusion rule, thus concluding that biacetyl should assume a conformation displaying an inversion centre, i.e. the planar trans form observed in the crystalline state. Furthermore, quantum chemical calculations [26-28] also predicted that the potential energy surface of diacetyl molecule in vacuum has a single minimum, corresponding to the trans conformer. On the other hand, diacetyl was shown to possess a permanent electric dipole moment in both the liquid and gaseous phases (ca. 1 D at room temperature,

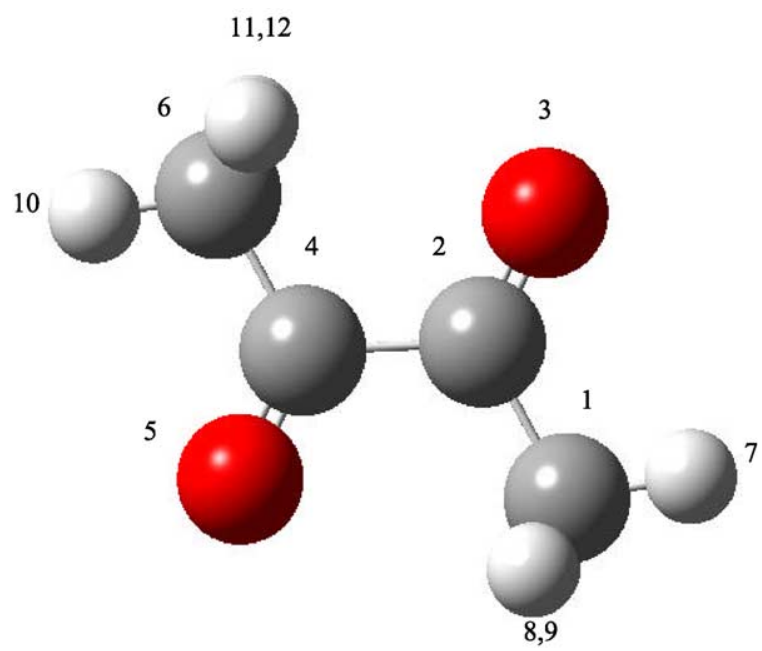

Fig. 1. Minimum energy conformation of diacetyl (trans form) with atom numbering. increasing with temperature) [29]. Apparently, such observation can be better conciliated with the above mentioned ${ }^{17} \mathrm{O}-\mathrm{NMR}$ solution results than with the previously reported vibrational spectroscopic and theoretical structural data.

In the present study, we report, for the first time, the IR spectrum of diacetyl isolated in a low temperature argon matrix at $9 \mathrm{~K}$, as well as that of the solid film of the pure compound, resulting from fast deposition of its room temperature vapour onto a suitable substrate cooled at $9 \mathrm{~K}$. The main idea was to try to freeze almost instantaneously at very low temperature the diacetyl molecules existing in the room temperature gas, and then use IR spectroscopy to probe their conformational arrangements. The two main experiments here reported were planned taking into consideration the different chemical environment existing when the molecules of the studied compound land onto the surface of the cold substrate, in order to examine the effects of geometrical constraint imposed by the media on the structural properties: in the matrix isolation experiment, they meet with an essentially crystalline environment (the argon crystal), whereas in the experiment where only the pure compound is deposited, the landing molecules arrive onto the amorphous layer resulting from the fast freezing of the vapour of the compound. These studies were complemented by temperature dependent IR experiments undertaken in the liquid phase, and receive further support from density functional theory (DFT) and Möller-Plesset to second order (MP2) molecular orbital calculations, and normal coordinate analysis.

\section{Materials and methods}

\subsection{Infrared spectroscopy}

The IR spectra of diacetyl (Aldrich; purity 99\%) were collected on a Mattson (Infinity 60AR Series) or Bomem (MB40) Fourier Transform infrared spectrometer equipped with a deuterated triglycine sulphate (DTGS) detector and $\mathrm{Ge} / \mathrm{KBr}$ and $\mathrm{Zn} / \mathrm{Se}$ beamsplitters, respectively, with $0.5 \mathrm{~cm}^{-1}\left(4 \mathrm{~cm}^{-1}\right.$ for liquid phase studies) spectral resolution.

In the matrix isolation experiments, a glass vacuum system and standard manometric procedures were used to deposit the matrix gas (argon N60, obtained 
from Air Liquid). Matrices were prepared by codeposition, onto the cooled CsI substrate of the cryostat, of the matrix gas and diacetyl placed in a specially designed doubly thermostattable Knudsen cell with shut-off possibility whose main component is a NUPRO SS4BMRG needle valve. The temperature of the cell can be controlled separately in the valve nozzle and the sample compartment, enabling a precise control of the saturated gas pressure over the liquid 2,3-butanedione and a better metering function of the valve. All experiments were done on the basis of an APD Cryogenics close-cycle helium refrigeration system with a DE-202A expander and, in all cases, the deposition temperature was $9 \mathrm{~K}$.

The low temperature solid amorphous layer was prepared in the same way as matrices but with the flux of matrix gas cut off. The layer was then allowed to anneal at slowly increasing temperature up to $170 \mathrm{~K}$. IR spectra were collected during this process every $10-20 \mathrm{~K}$ of temperature change. After the temperature exceeded $170 \mathrm{~K}$ the substrate was cooled back to $9 \mathrm{~K}$ and spectra collected each $10-20 \mathrm{~K}$ once more. Two cycles of annealing were performed by heating and cooling the sample between 9 and $170 \mathrm{~K}$.

For liquid state experiments a thin film of the compound was pressed within two sealed $\mathrm{KBr}$ windows assembled in a SPECAC variable temperature cell, controlled by a Red Lions digital temperature controller.

\subsection{Computational methodology}

The quantum chemical calculations were performed with GAUSSIAN 98 (Revision A.9) [30] at the DFT and MP2 levels of theory, using the 6$311++\mathrm{G}(\mathrm{d}, \mathrm{p})$ basis set [31]. The DFT calculations were carried out with the three-parameter density functional abbreviated as B3LYP, which includes Becke's gradient exchange correction [32] the Lee, Yang, Parr correlation functional [33] and the Vosko, Wilk and Nusair correlation functional [34].

Conformations were optimized at each level of theory using the Geometry Direct Inversion of the Invariant Subspace (GDIIS) method [35]. Vibrational frequencies were calculated at the DFT(B3LYP)/6$311++\mathrm{G}(\mathrm{d}, \mathrm{p})$ level and scaled down by a single factor (0.978) to correct them for the effects of basis set limitations, neglected part of electron correlation and anharmonicity effects in order to assist the analysis of the experimental spectra. Normal coordinates analyses were undertaken in the internal coordinates space as described by Schachtschneider [36] using the program BALGA and the optimised geometries and harmonic force constants resulting from the DFT(B3LYP)/6-311++G(d,p) calculations.

\section{Results and discussion}

In consonance with previous MO calculations undertaken at lower theoretical level of theory [26-28], the potential energy profile for internal rotation around the $\mathrm{C}-\mathrm{C}$ central bond in diacetyl, calculated in the present study both at the DFT and MP2/6-311++G(d,p) levels of approximation, was found to exhibit a single minimum, at the $\mathrm{O}=\mathrm{C}-\mathrm{C}=\mathrm{O}$ trans $C_{2 h}$ conformation. The calculated energy barrier associated with this internal rotation was predicted as 27.3 and $24.9 \mathrm{~kJ} \mathrm{~mol}^{-1}$ by the DFT and MP2 calculations, respectively. In Table 1 the calculated geometries for the minimum energy conformation are compared with available experimental data $[16,19]$. The agreement between the experimental structural parameters obtained for the molecule in the gaseous phase [19] and the calculated data is very good. In particular, the present calculations give further theoretical support to the observation that the $\mathrm{C}-\mathrm{C}$ central bond is longer than the $\mathrm{C}-\mathrm{C}$ (methyl) bonds; the calculated bond lengths are 154.5 and $150.5 \mathrm{pm}$ (MP2 results), respectively, which agree very well with the experimental values (153.0 and $151.5 \mathrm{pm}$ [19]). The bond length of the $\mathrm{C}-\mathrm{C}$ central bond in diacetyl is typical of a non-conjugated carbon-carbon bond and it results from the balance between the relatively weak $\pi$-electron delocalisation within the $\mathrm{O}=\mathrm{C}-\mathrm{C}=\mathrm{O}$ moiety (that tends to shorten this bond length) and the more important $\sigma$-electron system repulsion due to the interaction between the positively charged carbonyl carbon atoms (that tends to increase the carbon-carbon distance).

The DFT predicted methyl torsional energy barrier is $2.72 \mathrm{~kJ} \mathrm{~mol}^{-1}$, being similar to those previously reported for diacetyl $\left(2.51 \mathrm{~kJ} \mathrm{~mol}^{-1}, \mathrm{HF} / 3-21 \mathrm{G}\right.$, $3.91 \mathrm{~kJ} \mathrm{~mol}^{-1}$, MP2/6-31G*//3-21G [37]) and other similar molecules bearing a methyl group linked to a carbonyl moiety (e.g. acetic acid monomer, 
Table 1

Calculated and experimental geometries for diacetyl

\begin{tabular}{|c|c|c|c|c|}
\hline & \multicolumn{2}{|c|}{ Calculated } & \multicolumn{2}{|c|}{ Experimental } \\
\hline & DFT & MP2 & $\begin{array}{l}\text { Electron } \\
\text { diffraction } \\
\text { (gas) [19] }\end{array}$ & $\begin{array}{l}\text { X-ray } \\
\text { (crystal) [16] }\end{array}$ \\
\hline \multicolumn{5}{|l|}{ Bond lengths/pm } \\
\hline $\mathrm{C}_{1}-\mathrm{C}_{2}$ & 150.5 & 150.5 & 151.5 & 147.6 \\
\hline $\mathrm{C}_{1}-\mathrm{H}_{7}$ & 108.9 & 109.0 & $105.7^{\mathrm{a}}$ & 97.0 \\
\hline $\mathrm{C}_{1}-\mathrm{H}_{8}$ & 109.3 & 109.4 & & 91.0 \\
\hline $\mathrm{C}_{1}-\mathrm{H}_{9}$ & 109.3 & 109.4 & & 94.0 \\
\hline $\mathrm{C}_{2}=\mathrm{O}_{3}$ & 121.0 & 122.1 & 121.0 & 120.9 \\
\hline $\mathrm{C}_{2}-\mathrm{C}_{4}$ & 155.7 & 154.5 & 153.0 & 154.0 \\
\hline \multicolumn{5}{|l|}{ Bond angles $\rho$} \\
\hline $\mathrm{C}_{2}-\mathrm{C}_{1}-\mathrm{H}_{7}$ & 109.6 & 109.5 & $109.6^{\mathrm{a}}$ & 109.0 \\
\hline $\mathrm{C}_{2}-\mathrm{C}_{1}-\mathrm{H}_{8}$ & 110.1 & 109.7 & & 108.0 \\
\hline $\mathrm{C}_{2}-\mathrm{C}_{1}-\mathrm{H}_{9}$ & 110.1 & 109.7 & & 108.0 \\
\hline $\mathrm{H}_{7}-\mathrm{C}_{1}-\mathrm{H}_{8}$ & 110.5 & 110.6 & $109.3^{\mathrm{a}}$ & 111.0 \\
\hline $\mathrm{H}_{7}-\mathrm{C}_{1}-\mathrm{H}_{9}$ & 110.5 & 110.6 & & 112.0 \\
\hline $\mathrm{H}_{8}-\mathrm{C}_{1}-\mathrm{H}_{9}$ & 106.2 & 106.7 & & 109.0 \\
\hline $\mathrm{C}_{1}-\mathrm{C}_{2}=\mathrm{O}_{3}$ & 124.2 & 124.4 & 123.9 & 124.5 \\
\hline $\mathrm{C}_{1}-\mathrm{C}_{2}-\mathrm{C}_{4}$ & 116.6 & 116.4 & 116.6 & 116.7 \\
\hline $\mathrm{O}_{3}=\mathrm{C}_{2}-\mathrm{C}_{4}$ & 119.3 & 119.3 & 119.5 & 118.8 \\
\hline \multicolumn{5}{|l|}{ Dihedral angles $\rho$} \\
\hline $\mathrm{H}_{7}-\mathrm{C}_{1}-\mathrm{C}_{2}=\mathrm{O}_{3}$ & 0.0 & 0.0 & 0.0 & 0.0 \\
\hline $\mathrm{H}_{8}-\mathrm{C}_{1}-\mathrm{C}_{2}=\mathrm{O}_{3}$ & -121.7 & -121.5 & -120.0 & \\
\hline $\mathrm{H}_{9}-\mathrm{C}_{1}-\mathrm{C}_{2}=\mathrm{O}_{3}$ & 121.7 & 121.5 & 120.0 & \\
\hline $\mathrm{C}_{1}-\mathrm{C}_{2}-\mathrm{C}_{4}=\mathrm{O}_{5}$ & 0.0 & 0.0 & 0.0 & 0.0 \\
\hline $\mathrm{O}_{3}=\mathrm{C}_{2}-\mathrm{C}_{4}=\mathrm{O}_{5}$ & 180.0 & 180.0 & 180.0 & 180.0 \\
\hline
\end{tabular}

See Fig. 1 for atom numbering.

a Coordinate assumed to be equal for all hydrogen atoms.

$2.02 \mathrm{~kJ} \mathrm{~mol}^{-1}$ [38]; acetaldehyde, $4.85 \mathrm{~kJ} \mathrm{~mol}^{-1}$ [39]; acetone, $3.26 \mathrm{~kJ} \mathrm{~mol}^{-1}$ [40]). The value reported in Ref. [25], obtained from the gas phase near infrared absorption spectrum of diacetyl, $11.1 \mathrm{~kJ} \mathrm{~mol}^{-1}$, does not seem to be correct (though in the same paper the value extracted from solid-state near infrared data, $12.84 \mathrm{~kJ} \mathrm{~mol}^{-1}$ [25], has been found to agree reasonably with the value obtained from dipoledipole driven NMR spectroscopy for the methyl rotation barrier in solid diacetyl at $4 \mathrm{~K}$, $15.3 \mathrm{~kJ} \mathrm{~mol}^{-1}$ [41]).

The spectrum of diacetyl isolated in an argon matrix $(9 \mathrm{~K})$ is presented in Fig. 2, where it is compared with the calculated spectrum (DFT(B3LYP)/6-311++G(d,p) with uniform scaling) for the planar trans $\left(C_{2 h}\right)$ conformation of the molecule. The results of the normal coordinates analysis, made on the basis of the harmonic force field obtained from the DFT calculations, and band assignments are presented in Tables 2 and 3 .

It is clear from Fig. 2 that in the argon matrix diacetyl molecules assume the trans conformation, with exclusive observation in the experimental spectrum of the $C_{2 h}$ symmetry point group IR active vibrations ( $A_{u}$ and $B_{u}$ modes). The assignment of the fundamental bands is straightforward and strongly facilitated by the excellent agreement between the observed and calculated spectra, regarding both frequencies and intensities.

All expected fundamental bands but those expected to lie below $400 \mathrm{~cm}^{-1}(\gamma \mathrm{C}=\mathrm{O}, \delta \mathrm{C}-\mathrm{C}-\mathrm{C}$, $\tau \mathrm{CH}_{3}$ as and $\tau \mathrm{C}-\mathrm{C}$ ) were observed. With a single exception, the bands appear as closely spaced doublets, indicating that diacetyl molecules may occupy two slightly different substitutional sites in the argon matrix. In a $C_{2 h}$ symmetry molecule, first overtones are not IR active, since they belong to the totally symmetric irreducible representation $\left(\mathrm{A}_{\mathrm{g}}\right)$ of the group. However, besides the fundamentals, a number of combination tones were also observed, most of them appearing also split into two components due to matrix site splitting. For example, the $[(\nu \mathrm{C}=\mathrm{O}$ as $)+(\nu \mathrm{C}=\mathrm{O} \mathrm{s})]$ combination $\left(\mathrm{B}_{\mathrm{u}}\right.$ symmetry $)$ gives rise to the doublet of bands appearing at 3432 and $3429 \mathrm{~cm}^{-1},[(\delta \mathrm{C}=\mathrm{O}$ as $)+(\nu \mathrm{C}-\mathrm{C})]$ to the doublet observed at 1812 and $1810 \mathrm{~cm}^{-1}$, and $\left[\left(\delta \mathrm{CH}_{3} \mathrm{~s}\right.\right.$ $\left.\left.\mathrm{B}_{\mathrm{u}}\right)+(\delta \mathrm{C}-\mathrm{C}-\mathrm{C} \mathrm{s})\right]$ to that at 1735 and $1734 \mathrm{~cm}^{-1}$. Other features due to combinations are observed at $1391 \mathrm{~cm}^{-1}\left[\left(\delta \mathrm{CH}_{3} \mathrm{~s} \mathrm{~A}\right)+(\tau \mathrm{C}-\mathrm{C})\right], 1348 \mathrm{~cm}^{-1}$ $\left[(\gamma \mathrm{C}=\mathrm{O}\right.$ as $\left.)+\left(\gamma \mathrm{CH}_{3} \mathrm{~A}_{\mathrm{g}}\right)\right], 1225 / 1216 \mathrm{~cm}^{-1}[(\delta \mathrm{C}=\mathrm{O}$ as $\left.)+\left(\nu \mathrm{C}-\mathrm{C}\left(\mathrm{H}_{3}\right) \mathrm{s}\right)\right], \quad 1111 / 1107 \mathrm{~cm}^{-1}\left[\left(\gamma \mathrm{CH}_{3}\right.\right.$ $\left.\left.\mathrm{A}_{\mathrm{g}}\right)+\left(\tau \mathrm{CH}_{3} \mathrm{~A}_{\mathrm{u}}\right)\right]$ and $1034 \mathrm{~cm}^{-1}[(\delta \mathrm{C}=\mathrm{O}$ as $)+$ $(\delta \mathrm{C}=\mathrm{O} \mathrm{s})$ ]. Assignment of combination modes is not in general easy to undertake without support from anharmonic vibrational calculations. However, diacetyl has relatively sparse low energy vibrational energy levels and the number of active IR additive combination modes (subtractive combinations are not expected to be observed at low temperature) is relatively small. This leads to reduce the uncertainty in the assignment of combinations. The proposed assignments of the 1391 and $1111 / 1107 \mathrm{~cm}^{1}$ bands are of particular significance, since they enable to extract indirect information regarding the unobserved low frequency $\mathrm{C}-\mathrm{C}$ and $\mathrm{CH}_{3}\left(\mathrm{~A}_{\mathrm{u}}\right)$ torsional vibrations; 


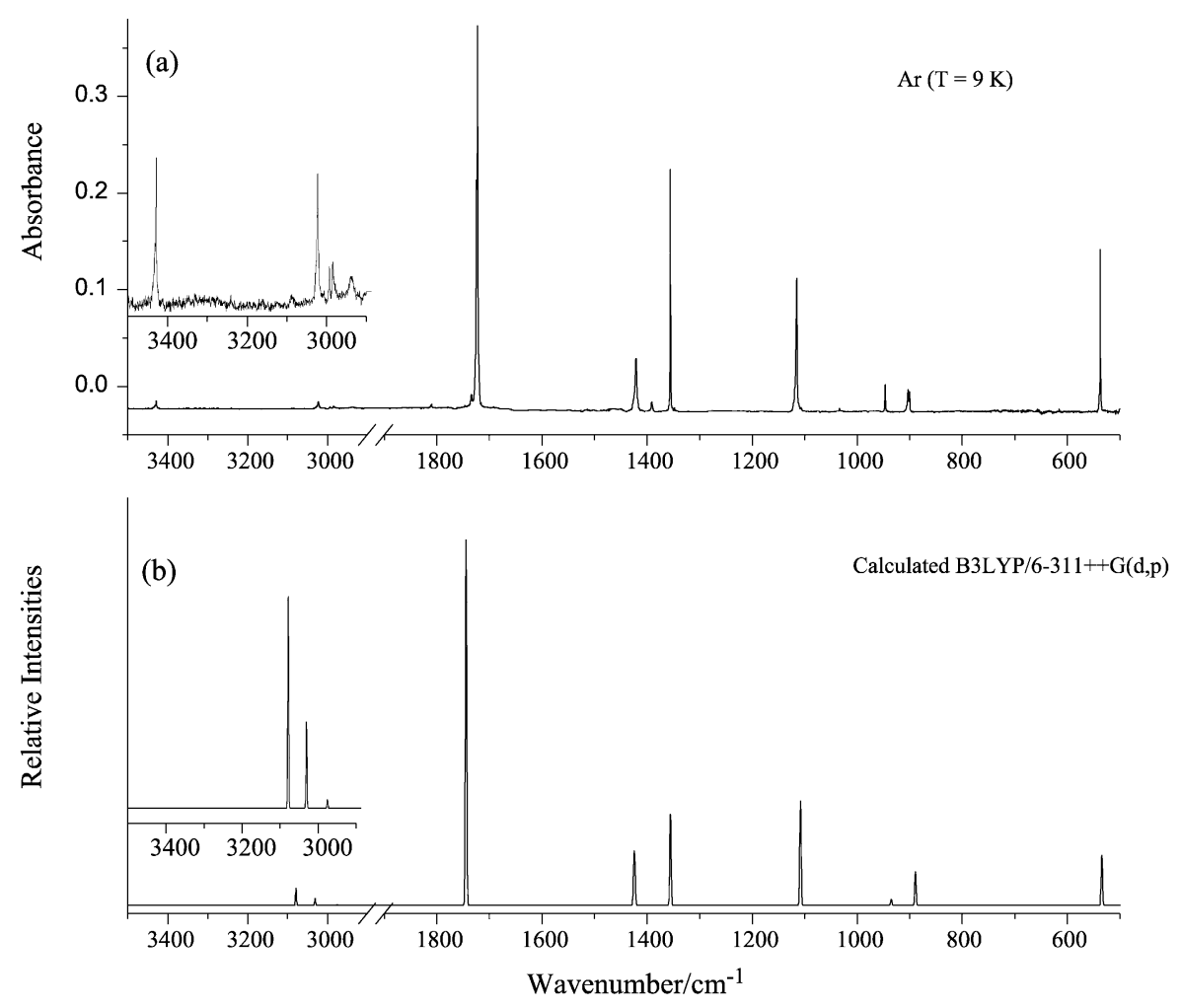

Fig. 2. a: Infrared spectrum of diacetyl in an argon matrix $(T=9 \mathrm{~K})$ and $\mathrm{b}$ : DFT(B3LYP)/6-311++G(d,p) calculated spectrum for the minimum energy trans conformation.

accordingly, these can be estimated to occur at ca. 30 and $105 \mathrm{~cm}^{1}$, respectively, in good agreement with their theoretically predicted frequencies (see Table 3 ).

Fig. 3 shows the spectrum of the amorphous layer of diacetyl, obtained by fast deposition of the room temperature vapour of the substance onto de cold substrate of the cryostat (at $9 \mathrm{~K}$ ), together with that of the repeatedly annealed sample (two warming/cooling cycles were performed, with the final spectra recorded at $9 \mathrm{~K}$ ).

The spectrum of the annealed sample closely matches that previously reported for polycrystalline diacetyl at $77 \mathrm{~K}$ [25] and, as for the matrix isolated compound, the spectrum clearly indicates that diacetyl exists in the crystal exclusively in the $C_{2 h}$ symmetry trans conformation, with exclusive observation of IR active $A_{u}$ and $B_{u}$ fundamentals. The assignment of the crystalline state IR spectrum closely follows that made by Durig et al. [25], though the order of appearance of the $\gamma \mathrm{CH}_{3}$ rocking modes
$\left(\mathrm{B}_{\mathrm{u}}\right.$ and $\mathrm{A}_{\mathrm{u}}$ ) and $\nu \mathrm{C}-\mathrm{C}\left(\mathrm{H}_{3}\right) \mathrm{B}_{\mathrm{u}}$ stretching vibration was changed in consonance with the theoretical predictions. The assignment of the $\delta \mathrm{CH}_{3}$ vibrations in the $1450-1350 \mathrm{~cm}^{-1}$ spectral region was also reviewed accordingly with the results of the theoretical predictions. The band at $1419 \mathrm{~cm}^{-1}$ is now assigned to the $\delta \mathrm{CH}_{3}$ as vibration of $\mathrm{B}_{\mathrm{u}}$ symmetry and the bands at 1429 and $1400 \mathrm{~cm}^{-1}$ to $\delta \mathrm{CH}_{3}$ as $\mathrm{A}_{\mathrm{u}}$ in Fermi resonance (FR) with the $\left[\left(\delta \mathrm{CH}_{3} \mathrm{~s}\right.\right.$ $\left.\left.\mathrm{A}_{\mathrm{g}}\right)+(\tau \mathrm{C}-\mathrm{C})\right]$ combination. The calculations predict the two $\delta \mathrm{CH}_{3}$ as modes with nearly the same frequency and close to that at which the mode of $\mathrm{B}_{\mathrm{u}}$ symmetry is observed. However, since the $\tau \mathrm{C}-\mathrm{C}$ torsional mode in the crystal appears at $66 \mathrm{~cm}^{-1}$ [25], thus doubling its frequency compared to those estimated for both the gas phase and matrix-isolated diacetyl (see Table 3$)$, the $\left[\left(\delta \mathrm{CH}_{3} \mathrm{~s} \mathrm{~A}_{\mathrm{g}}\right)+(\tau \mathrm{C}-\mathrm{C})\right]$ combination, which has $\mathrm{A}_{\mathrm{u}}$ symmetry, blue shifts and can now interact with the $\delta \mathrm{CH}_{3}$ as mode of the same symmetry by FR, justifying the observation of the 
Table 2

Definition of symmetry coordinates for diacetyl

\begin{tabular}{|c|c|c|c|}
\hline & Definition $^{\mathrm{a}}$ & Symmetry ${ }^{\mathrm{b}}$ & $\begin{array}{l}\text { Approximate } \\
\text { description }\end{array}$ \\
\hline $\mathrm{S}_{1}$ & $\nu\left(\mathrm{C}_{2}=\mathrm{O}_{3}\right)+\nu\left(\mathrm{C}_{4}=\mathrm{O}_{5}\right)$ & $\mathrm{A}_{\mathrm{g}}$ & $\nu \mathrm{C}=\mathrm{O} \mathrm{s}$ \\
\hline $\mathrm{S}_{2}$ & $\nu\left(\mathrm{C}_{2}=\mathrm{O}_{3}\right)-\nu\left(\mathrm{C}_{4}=\mathrm{O}_{5}\right)$ & $\mathrm{B}_{\mathrm{u}}$ & $\nu \mathrm{C}=\mathrm{O}$ as \\
\hline $\mathrm{S}_{3}$ & $\nu\left(\mathrm{C}_{2}-\mathrm{C}_{4}\right)$ & $\mathrm{A}_{\mathrm{g}}$ & $\nu \mathrm{C}-\mathrm{C}$ \\
\hline $\mathrm{S}_{4}$ & $\nu\left(\mathrm{C}_{1}-\mathrm{C}_{2}\right)+\nu\left(\mathrm{C}_{4}-\mathrm{C}_{6}\right)$ & $A_{g}$ & $\nu \mathrm{C}-\mathrm{C}\left(\mathrm{H}_{3}\right) \mathrm{s}$ \\
\hline $\mathrm{S}_{5}$ & $\nu\left(\mathrm{C}_{1}-\mathrm{C}_{2}\right)-\nu\left(\mathrm{C}_{4}-\mathrm{C}_{6}\right)$ & $\mathrm{B}_{\mathrm{u}}$ & $\nu \mathrm{C}-\mathrm{C}\left(\mathrm{H}_{3}\right)$ as \\
\hline $\mathrm{S}_{6}$ & $\nu\left(\mathrm{C}_{1}-\mathrm{H}_{7}\right)+\nu\left(\mathrm{C}_{1}-\mathrm{H}_{8}\right)+\nu\left(\mathrm{C}_{1}-\mathrm{H}_{9}\right)+\nu\left(\mathrm{C}_{6}-\mathrm{H}_{10}\right)+\nu\left(\mathrm{C}_{6}-\mathrm{H}_{11)}+\nu\left(\mathrm{C}_{6}-\mathrm{H}_{12}\right)\right.$ & $A_{g}$ & $\nu \mathrm{CH}_{3} \mathrm{~s}$ \\
\hline $\mathrm{S}_{7}$ & $\nu\left(\mathrm{C}_{1}-\mathrm{H}_{7}\right)+\nu\left(\mathrm{C}_{1}-\mathrm{H}_{8}\right)+\nu\left(\mathrm{C}_{1}-\mathrm{H}_{9}\right)-\nu\left(\mathrm{C}_{6}-\mathrm{H}_{10}\right)-\nu\left(\mathrm{C}_{6}-\mathrm{H}_{11}\right)-\nu\left(\mathrm{C}_{6}-\mathrm{H}_{12}\right)$ & $\mathrm{B}_{\mathrm{u}}$ & $\nu \mathrm{CH}_{3} \mathrm{~s}$ \\
\hline $\mathrm{S}_{8}$ & $2 \nu\left(\mathrm{C}_{1}-\mathrm{H}_{7}\right)-\nu\left(\mathrm{C}_{1}-\mathrm{H}_{8}\right)-\nu\left(\mathrm{C}_{1}-\mathrm{H}_{9}\right)+2 \nu\left(\mathrm{C}_{6}-\mathrm{H}_{10}\right)-\nu\left(\mathrm{C}_{6}-\mathrm{H}_{11}\right)-\nu\left(\mathrm{C}_{6}-\mathrm{H}_{12}\right)$ & $\mathrm{A}_{\mathrm{g}}$ & $\nu \mathrm{CH}_{3}$ as \\
\hline $\mathrm{S}_{9}$ & $2 \nu\left(\mathrm{C}_{1}-\mathrm{H}_{7}\right)-\nu\left(\mathrm{C}_{1}-\mathrm{H}_{8}\right)-\nu\left(\mathrm{C}_{1}-\mathrm{H}_{9}\right)-2 \nu\left(\mathrm{C}_{6}-\mathrm{H}_{10}\right)+\nu\left(\mathrm{C}_{6}-\mathrm{H}_{11}\right)+\nu\left(\mathrm{C}_{6}-\mathrm{H}_{12}\right)$ & $\mathrm{B}_{\mathrm{u}}$ & $\nu \mathrm{CH}_{3}$ as \\
\hline $\mathrm{S}_{10}$ & $\nu\left(\mathrm{C}_{1}-\mathrm{H}_{8}\right)-\nu\left(\mathrm{C}_{1}-\mathrm{H}_{9}\right)+\nu\left(\mathrm{C}_{6}-\mathrm{H}_{11}\right)-\nu\left(\mathrm{C}_{6}-\mathrm{H}_{12}\right)$ & $\mathrm{B}_{\mathrm{g}}$ & $\nu \mathrm{CH}_{3}$ as \\
\hline $\mathrm{S}_{11}$ & $\nu\left(\mathrm{C}_{1}-\mathrm{H}_{8}\right)-\nu\left(\mathrm{C}_{1}-\mathrm{H}_{9}\right)-\nu\left(\mathrm{C}_{6}-\mathrm{H}_{11}\right)+\nu\left(\mathrm{C}_{6}-\mathrm{H}_{12}\right)$ & $\mathrm{A}_{\mathrm{u}}$ & $\nu \mathrm{CH}_{3}$ as \\
\hline $\mathrm{S}_{12}$ & $\delta\left(\mathrm{O}_{3}=\mathrm{C}_{2}-\mathrm{C}_{4}\right)-\delta\left(\mathrm{C}_{1}-\mathrm{C}_{2}=\mathrm{O}_{3}\right)+\delta\left(\mathrm{O}_{5}=\mathrm{C}_{4}-\mathrm{C}_{2}\right)-\delta\left(\mathrm{C}_{6}-\mathrm{C}_{4}=\mathrm{O}_{5}\right)$ & $\mathrm{A}_{\mathrm{g}}$ & $\delta \mathrm{C}=\mathrm{O} \mathrm{s}$ \\
\hline $\mathrm{S}_{13}$ & $\delta\left(\mathrm{O}_{3}=\mathrm{C}_{2}-\mathrm{C}_{4}\right)-\delta\left(\mathrm{C}_{1}-\mathrm{C}_{2}=\mathrm{O}_{3}\right)-\delta\left(\mathrm{O}_{5}=\mathrm{C}_{4}-\mathrm{C}_{2}\right)+\delta\left(\mathrm{C}_{6}-\mathrm{C}_{4}=\mathrm{O}_{5}\right)$ & $\mathrm{B}_{\mathrm{u}}$ & $\delta \mathrm{C}=\mathrm{O}$ as \\
\hline $\mathrm{S}_{14}$ & $\begin{array}{l}2 \delta\left(\mathrm{C}_{1}-\mathrm{C}_{2}-\mathrm{C}_{4}\right)-\delta\left(\mathrm{O}_{3}=\mathrm{C}_{2}-\mathrm{C}_{4}\right)-\delta\left(\mathrm{C}_{1}-\mathrm{C}_{2}=\mathrm{O}_{3}\right)+2 \delta\left(\mathrm{C}_{6}-\mathrm{C}_{4}-\mathrm{C}_{2}\right) \\
-\delta\left(\mathrm{O}_{5}=\mathrm{C}_{4}-\mathrm{C}_{2}\right)-\delta\left(\mathrm{C}_{6}-\mathrm{C}_{4}=\mathrm{O}_{5}\right)\end{array}$ & $\mathrm{A}_{\mathrm{g}}$ & $\delta \mathrm{C}-\mathrm{C}-\mathrm{C} \mathrm{s}$ \\
\hline$S_{15}$ & $\begin{array}{l}2 \delta\left(\mathrm{C}_{1}-\mathrm{C}_{2}-\mathrm{C}_{4}\right)-\delta\left(\mathrm{O}_{3}=\mathrm{C}_{2}-\mathrm{C}_{4}\right)-\delta\left(\mathrm{C}_{1}-\mathrm{C}_{2}=\mathrm{O}_{3}\right)-\delta\left(\mathrm{C}_{6}-\mathrm{C}_{4}-\mathrm{C}_{2}\right) \\
+\delta\left(\mathrm{O}_{5}=\mathrm{C}_{4}-\mathrm{C}_{2}\right)+\delta\left(\mathrm{C}_{6}-\mathrm{C}_{4}=\mathrm{O}_{5}\right)\end{array}$ & $\mathrm{B}_{\mathrm{u}}$ & $\delta \mathrm{C}-\mathrm{C}-\mathrm{C}$ as \\
\hline$S_{16}$ & $\begin{array}{l}\delta\left(\mathrm{H}_{10}-\mathrm{C}_{6}-\mathrm{H}_{11}\right)+\delta\left(\mathrm{H}_{11}-\mathrm{C}_{6}-\mathrm{H}_{12}\right)+\delta\left(\mathrm{H}_{10}-\mathrm{C}_{6}-\mathrm{H}_{12}\right)-\delta\left(\mathrm{H}_{10}-\mathrm{C}_{6}-\mathrm{C}_{4}\right) \\
-\delta\left(\mathrm{H}_{11}-\mathrm{C}_{6}-\mathrm{C}_{4}\right)-\delta\left(\mathrm{H}_{12}-\mathrm{C}_{4}-\mathrm{C}_{6}\right)+\delta\left(\mathrm{H}_{7}-\mathrm{C}_{1}-\mathrm{H}_{8}\right)+\delta\left(\mathrm{H}_{8}-\mathrm{C}_{1}-\mathrm{H}_{9}\right) \\
+\delta\left(\mathrm{H}_{7}-\mathrm{C}_{1}-\mathrm{H}_{9}\right)-\delta\left(\mathrm{H}_{7}-\mathrm{C}_{1}-\mathrm{C}_{2}\right)-\delta\left(\mathrm{H}_{8}-\mathrm{C}_{1}-\mathrm{C}_{2}\right)-\delta\left(\mathrm{H}_{9}-\mathrm{C}_{1}-\mathrm{C}_{2}\right)\end{array}$ & $\mathrm{A}_{\mathrm{g}}$ & $\delta \mathrm{CH}_{3 \mathrm{~s}}$ \\
\hline $\mathrm{S}_{17}$ & $\begin{array}{l}\delta\left(\mathrm{H}_{10}-\mathrm{C}_{6}-\mathrm{H}_{11}\right)+\delta\left(\mathrm{H}_{11}-\mathrm{C}_{6}-\mathrm{H}_{12}\right)+\delta\left(\mathrm{H}_{10}-\mathrm{C}_{6}-\mathrm{H}_{12}\right)-\delta\left(\mathrm{H}_{10}-\mathrm{C}_{6}-\mathrm{C}_{4}\right) \\
-\delta\left(\mathrm{H}_{11}-\mathrm{C}_{6}-\mathrm{C}_{4}\right)-\delta\left(\mathrm{H}_{12}-\mathrm{C}_{4}-\mathrm{C}_{6}\right)-\delta\left(\mathrm{H}_{7}-\mathrm{C}_{1}-\mathrm{H}_{8}\right)-\delta\left(\mathrm{H}_{8}-\mathrm{C}_{1}-\mathrm{H}_{9}\right) \\
-\delta\left(\mathrm{H}_{7}-\mathrm{C}_{1}-\mathrm{H}_{9}\right)+\delta\left(\mathrm{H}_{7}-\mathrm{C}_{1}-\mathrm{C}_{2}\right)+\delta\left(\mathrm{H}_{8}-\mathrm{C}_{1}-\mathrm{C}_{2}\right)+\delta\left(\mathrm{H}_{9}-\mathrm{C}_{1}-\mathrm{C}_{2}\right)\end{array}$ & $\mathrm{B}_{\mathrm{u}}$ & $\delta \mathrm{CH}_{3} \mathrm{~s}$ \\
\hline$S_{18}$ & $\begin{array}{l}2 \delta\left(\mathrm{H}_{10}-\mathrm{C}_{6}-\mathrm{H}_{11}\right)-\delta\left(\mathrm{H}_{11}-\mathrm{C}_{6}-\mathrm{H}_{12}\right)-\delta\left(\mathrm{H}_{10}-\mathrm{C}_{6}-\mathrm{H}_{12}\right)+2 \delta\left(\mathrm{H}_{7}-\mathrm{C}_{1}-\mathrm{H}_{8}\right) \\
-\delta\left(\mathrm{H}_{8}-\mathrm{C}_{1}-\mathrm{H}_{9}\right)-\delta\left(\mathrm{H}_{7}-\mathrm{C}_{1}-\mathrm{H}_{9}\right)\end{array}$ & $\mathrm{A}_{\mathrm{g}}$ & $\delta \mathrm{CH}_{3}$ as \\
\hline $\mathrm{S}_{19}$ & $\begin{array}{l}2 \delta\left(\mathrm{H}_{10}-\mathrm{C}_{6}-\mathrm{H}_{11}\right)-\delta\left(\mathrm{H}_{11}-\mathrm{C}_{6}-\mathrm{H}_{12}\right)-\delta\left(\mathrm{H}_{10}-\mathrm{C}_{6}-\mathrm{H}_{12}\right)-\delta\left(\mathrm{H}_{7}-\mathrm{C}_{1}-\mathrm{H}_{8}\right) \\
+\delta\left(\mathrm{H}_{8}-\mathrm{C}_{1}-\mathrm{H}_{9}\right)+\delta\left(\mathrm{H}_{7}-\mathrm{C}_{1}-\mathrm{H}_{9}\right)\end{array}$ & $\mathrm{B}_{\mathrm{u}}$ & $\delta \mathrm{CH}_{3}$ as \\
\hline $\mathrm{S}_{20}$ & $\delta\left(\mathrm{H}_{11}-\mathrm{C}_{6}-\mathrm{H}_{12}\right)-\delta\left(\mathrm{H}_{10}-\mathrm{C}_{6}-\mathrm{H}_{12}\right)+\delta\left(\mathrm{H}_{8}-\mathrm{C}_{1}-\mathrm{H}_{9}\right)-\delta\left(\mathrm{H}_{7}-\mathrm{C}_{1}-\mathrm{H}_{9}\right)$ & $\mathrm{B}_{\mathrm{g}}$ & $\delta \mathrm{CH}_{3}$ as \\
\hline $\mathrm{S}_{21}$ & $\delta\left(\mathrm{H}_{11}-\mathrm{C}_{6}-\mathrm{H}_{12}\right)-\delta\left(\mathrm{H}_{10}-\mathrm{C}_{6}-\mathrm{H}_{12}\right)-\delta\left(\mathrm{H}_{8}-\mathrm{C}_{1}-\mathrm{H}_{9}\right)+\delta\left(\mathrm{H}_{7}-\mathrm{C}_{1}-\mathrm{H}_{9}\right)$ & $A_{u}$ & $\delta \mathrm{CH}_{3}$ as \\
\hline $\mathrm{S}_{22}$ & $\begin{array}{l}2 \delta\left(\mathrm{H}_{10}-\mathrm{C}_{6}-\mathrm{C}_{4}\right)-\delta\left(\mathrm{H}_{11}-\mathrm{C}_{6}-\mathrm{C}_{4}\right)-\delta\left(\mathrm{H}_{12}-\mathrm{C}_{6}-\mathrm{C}_{4}\right)+2 \delta\left(\mathrm{H}_{7}-\mathrm{C}_{1}-\mathrm{C}_{2}\right) \\
-\delta\left(\mathrm{H}_{8}-\mathrm{C}_{1}-\mathrm{C}_{2}\right)-\delta\left(\mathrm{H}_{9}-\mathrm{C}_{1}-\mathrm{C}_{2}\right)\end{array}$ & $\mathrm{A}_{\mathrm{g}}$ & $\gamma \mathrm{CH}_{3}$ \\
\hline $\mathrm{S}_{23}$ & $\begin{array}{l}2 \delta\left(\mathrm{H}_{10}-\mathrm{C}_{6}-\mathrm{C}_{4}\right)-\delta\left(\mathrm{H}_{11}-\mathrm{C}_{6}-\mathrm{C}_{4}\right)-\delta\left(\mathrm{H}_{12}-\mathrm{C}_{6}-\mathrm{C}_{4}\right)-\delta\left(\mathrm{H}_{7}-\mathrm{C}_{1}-\mathrm{C}_{2}\right) \\
+\delta\left(\mathrm{H}_{8}-\mathrm{C}_{1}-\mathrm{C}_{2}\right)+\delta\left(\mathrm{H}_{9}-\mathrm{C}_{1}-\mathrm{C}_{2}\right)\end{array}$ & $\mathrm{B}_{\mathrm{u}}$ & $\gamma \mathrm{CH}_{3}$ \\
\hline $\mathrm{S}_{24}$ & $\delta\left(\mathrm{H}_{11}-\mathrm{C}_{6}-\mathrm{C}_{4}\right)-\delta\left(\mathrm{H}_{12}-\mathrm{C}_{6}-\mathrm{C}_{4}\right)+\delta\left(\mathrm{H}_{8}-\mathrm{C}_{1}-\mathrm{C}_{2}\right)-\delta\left(\mathrm{H}_{9}-\mathrm{C}_{1}-\mathrm{C}_{2}\right)$ & $\mathrm{B}_{\mathrm{g}}$ & $\gamma \mathrm{CH}_{3}$ \\
\hline $\mathrm{S}_{25}$ & $\delta\left(\mathrm{H}_{11}-\mathrm{C}_{6}-\mathrm{C}_{4}\right)-\delta\left(\mathrm{H}_{12}-\mathrm{C}_{6}-\mathrm{C}_{4}\right)-\delta\left(\mathrm{H}_{8}-\mathrm{C}_{1}-\mathrm{C}_{2}\right)+\delta\left(\mathrm{H}_{9}-\mathrm{C}_{1}-\mathrm{C}_{2}\right)$ & $\mathrm{A}_{\mathrm{u}}$ & $\gamma \mathrm{CH}_{3}$ \\
\hline $\mathrm{S}_{26}$ & $\tau\left(\mathrm{O}_{5}=\mathrm{C}_{4}-\mathrm{C}_{2}=\mathrm{O}_{3}\right)$ & $\mathrm{A}_{\mathrm{u}}$ & $\pi \mathrm{C}-\mathrm{C}$ \\
\hline $\mathrm{S}_{27}$ & $\tau\left(\mathrm{H}_{10}-\mathrm{C}_{6}-\mathrm{C}_{4}-\mathrm{C}_{2}\right)+\tau\left(\mathrm{H}_{7}-\mathrm{C}_{1}-\mathrm{C}_{2}-\mathrm{C}_{4}\right)$ & $\mathrm{B}_{\mathrm{g}}$ & $\tau \mathrm{CH}_{3} \mathrm{~s}$ \\
\hline $\mathrm{S}_{28}$ & $\tau\left(\mathrm{H}_{10}-\mathrm{C}_{6}-\mathrm{C}_{4}-\mathrm{C}_{2}\right)-\tau\left(\mathrm{H}_{7}-\mathrm{C}_{1}-\mathrm{C}_{2}-\mathrm{C}_{4}\right)$ & $\mathrm{A}_{\mathrm{u}}$ & $\tau \mathrm{CH}_{3}$ as \\
\hline $\mathrm{S}_{29}$ & $\mathrm{O}_{3}$ out of plane $\mathrm{C}_{1}-\mathrm{C}_{2}-\mathrm{C}_{4+} \mathrm{O}_{5}$ out of plane $\mathrm{C}_{2}-\mathrm{C}_{4}-\mathrm{C}_{6}$ & $\mathrm{~B}_{\mathrm{g}}$ & $\gamma \mathrm{C}=\mathrm{Os}$ \\
\hline $\mathrm{S}_{30}$ & $\mathrm{O}_{3}$ out of plane $\mathrm{C}_{1}-\mathrm{C}_{2}-\mathrm{C}_{4}-\mathrm{O}_{5}$ out of plane $\mathrm{C}_{2}-\mathrm{C}_{4}-\mathrm{C}_{6}$ & $\mathrm{~A}_{\mathrm{u}}$ & $\gamma \mathrm{C}=\mathrm{O}$ as \\
\hline
\end{tabular}

${ }^{\text {a }}$ Normalization factors not shown. $\nu$, bond stretching, $\delta$, bending, $\gamma$, rocking, $\tau$, torsion. See Fig. 1 for atom numbering.

${ }^{\text {b }} C_{2 h}$ symmetry point group.

bands at 1429 and $1400 \mathrm{~cm}^{-1}$, as mentioned above. A FR interaction involving the $\gamma \mathrm{CH}_{3} \mathrm{~A}_{\mathrm{u}}$ fundamental and the $[(\gamma \mathrm{C}=\mathrm{O}$ as $)+(\gamma \mathrm{C}=\mathrm{O} \mathrm{s})]$ combination mode with the same symmetry may also be the origin of the appearance of the doublet of bands at 957/
$951 \mathrm{~cm}^{-1}$, as well as in the case of the 1719/ $1711 \mathrm{~cm}^{-1}\left\{\nu \mathrm{C}=\mathrm{O}\right.$ as in $\mathrm{FR}$ with $\left[\left(\delta \mathrm{CH}_{3} \mathrm{~s}\right.\right.$ $\left.\left.\left.\mathrm{B}_{\mathrm{u}}\right)+(\delta \mathrm{C}-\mathrm{C}-\mathrm{C} \mathrm{s})\right]\right\}$ and $1126 / 1119 \mathrm{~cm}^{-1}\left\{\gamma \mathrm{CH}_{3}\right.$ $\mathrm{B}_{\mathrm{u}}$ in $\mathrm{FR}$ with $\left[\left(\nu \mathrm{C}-\mathrm{C}\left(\mathrm{H}_{3}\right)\right.\right.$ as $\left.\left.)+\left(\tau \mathrm{CH}_{3} \mathrm{~B}_{\mathrm{g}}\right)\right]\right\}$ pairs of bands. However, since the number of diacetyl 
Table 3

Experimental and calculated vibrational data, and results of normal coordinate analysis for diacetyl



Wavenumbers in $\mathrm{cm}^{-1}$, calculated intensities in $\mathrm{km} \mathrm{mol}^{-1}, \nu$, bond stretching, $\delta$, bending, $\gamma$, rocking, $\tau$, torsion. n.o., not observed; n.i., not investigated. See Table 2 for definition of symmetry coordinates.

a Only PED values greater than $10 \%$ are given.

${ }^{\mathrm{b}}$ Scaled (0.978).

c Intensities were presented as normalized intensities, being calculated using the formula $I_{i}^{\text {(normalized) }}$

integrated absorbance of the band $\mathrm{i}$, and the sums extend to all bands that were observed experimentaly.

d Estimated on the basis of the observed frequencies of $\left[(\gamma \mathrm{C}=\mathrm{O}\right.$ as $\left.)+\left(\gamma \mathrm{CH}_{3} \mathrm{~A}_{\mathrm{g}}\right)\right],\left[\left(\gamma \mathrm{CH}_{3} \mathrm{~A}_{\mathrm{g}}\right)+\left(\tau \mathrm{CH}_{3} \mathrm{~A}_{\mathrm{u}}\right)\right]$ and $\left[\left(\delta \mathrm{CH}_{3} \mathrm{~s} \mathrm{~A}_{\mathrm{g}}\right)+(\tau \mathrm{C}-\mathrm{C})\right]$ combination tones and observed frequencies for $\gamma \mathrm{CH}_{3} \mathrm{~A}_{\mathrm{g}}$ and $\delta \mathrm{CH}_{3 \mathrm{~s}} \mathrm{~A}_{\mathrm{g}}$ fundamentals in the IR spectrum of the glass (see text). 


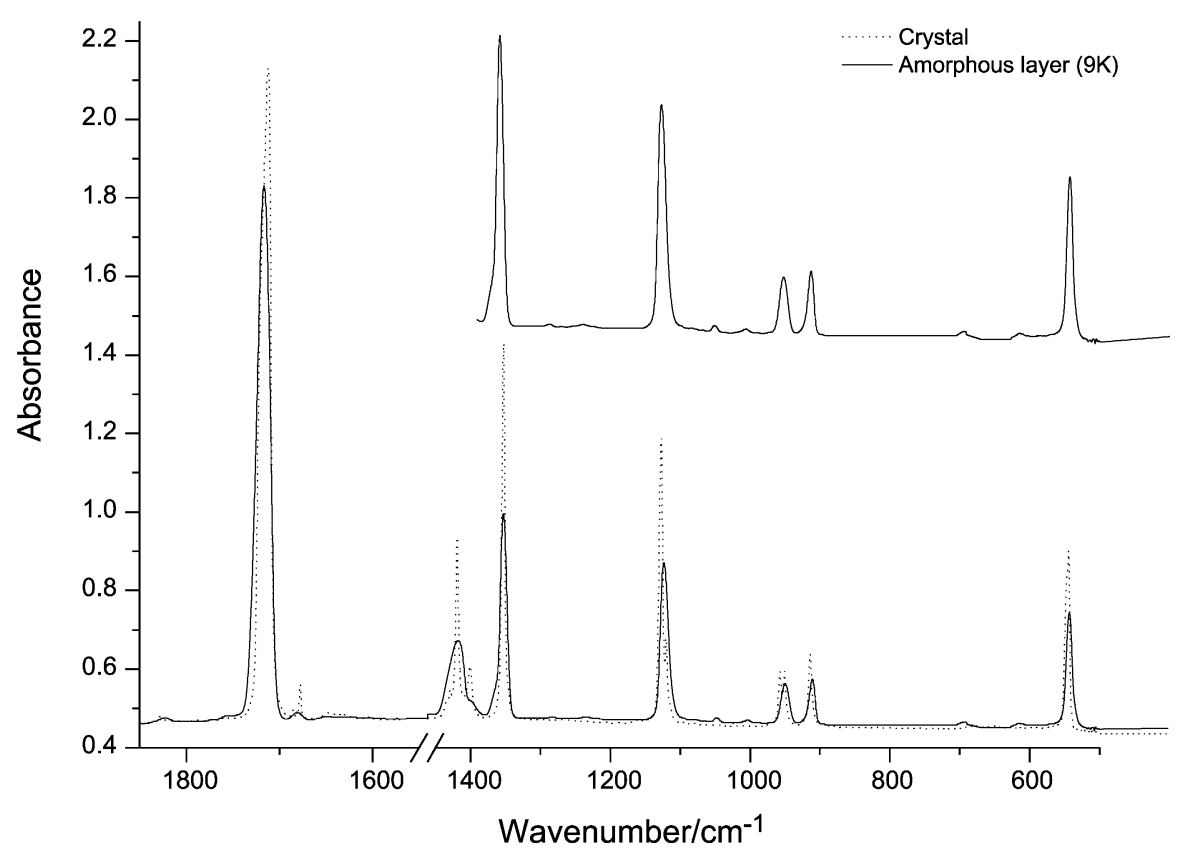

Fig. 3. Infrared spectra of diacetyl: solid amorphous layer (-); crystal ( $\cdots \cdots \cdots \cdot)$.

molecules in the crystalline unit cell is 2 [16], an alternative explanation for the appearance of at least part of these doublets is crystal field splitting, which can also lead to observation of pairs of bands involving the same monomer vibration [42].

The spectrum of the amorphous phase differs from that of the crystalline state: bandwidths increase considerably, the peak frequencies of the bands corresponding to those observed in the crystal shift, and a new set of low intensity bands is observed. All these differences can be explained assuming that conformations with lower symmetry than $C_{2 h}$ contribute to the observed spectrum, as discussed in detail below.

Diacetyl lowest vibrational mode corresponds to the large amplitude torsional vibration around the central $\mathrm{C}-\mathrm{C}$ bond (estimated frequency: ca. $30 \mathrm{~cm}^{-1}$; see Table 3). This is a similar situation to that observed for dimethyl oxalate (DMO; $\mathrm{CH}_{3-}$ $\left.\mathrm{OC}(=\mathrm{O}) \mathrm{C}(=\mathrm{O}) \mathrm{OCH}_{3}\right)[42]$ that differs structurally from diacetyl by having the two methyl groups replaced by methoxyl groups. For DMO, whose minimum energy conformation is as in diacetyl a trans $C_{2 h}$ structure, it was shown [42] that, during the low temperature glassy state formation by fast deposition of the vapour of the compound onto a cold substrate, a significant amount of molecules was frozen in a non-trans geometry as a result of the large amplitude low frequency torsion around the central $\mathrm{C}-\mathrm{C}$ bond. Indeed, a number of additional bands with respect to the IR spectrum of the trans form were observed and unequivocally assigned to vibrations that can only be IR active for lower symmetry conformations produced by the torsional movement. Also as observed in the case of diacetyl, repeated annealing of the amorphous layer led to production of a well-organized crystal of DMO, with molecules exclusively adopting the trans conformation [42]. Hence, a similar explanation can be used to justify the above mentioned experimental observations in the case of diacetyl. Fig. 4 shows the DFT(B3LYP/6$311++\mathrm{G}(\mathrm{d}, \mathrm{p})$ calculated dependence of the frequency of the fundamental vibrations of diacetyl with the $\mathrm{O}=\mathrm{C}-\mathrm{C}=\mathrm{O}$ dihedral. From this figure, it can be easily concluded that, assuming the contribution of non-trans molecules for the IR spectrum of amor- 


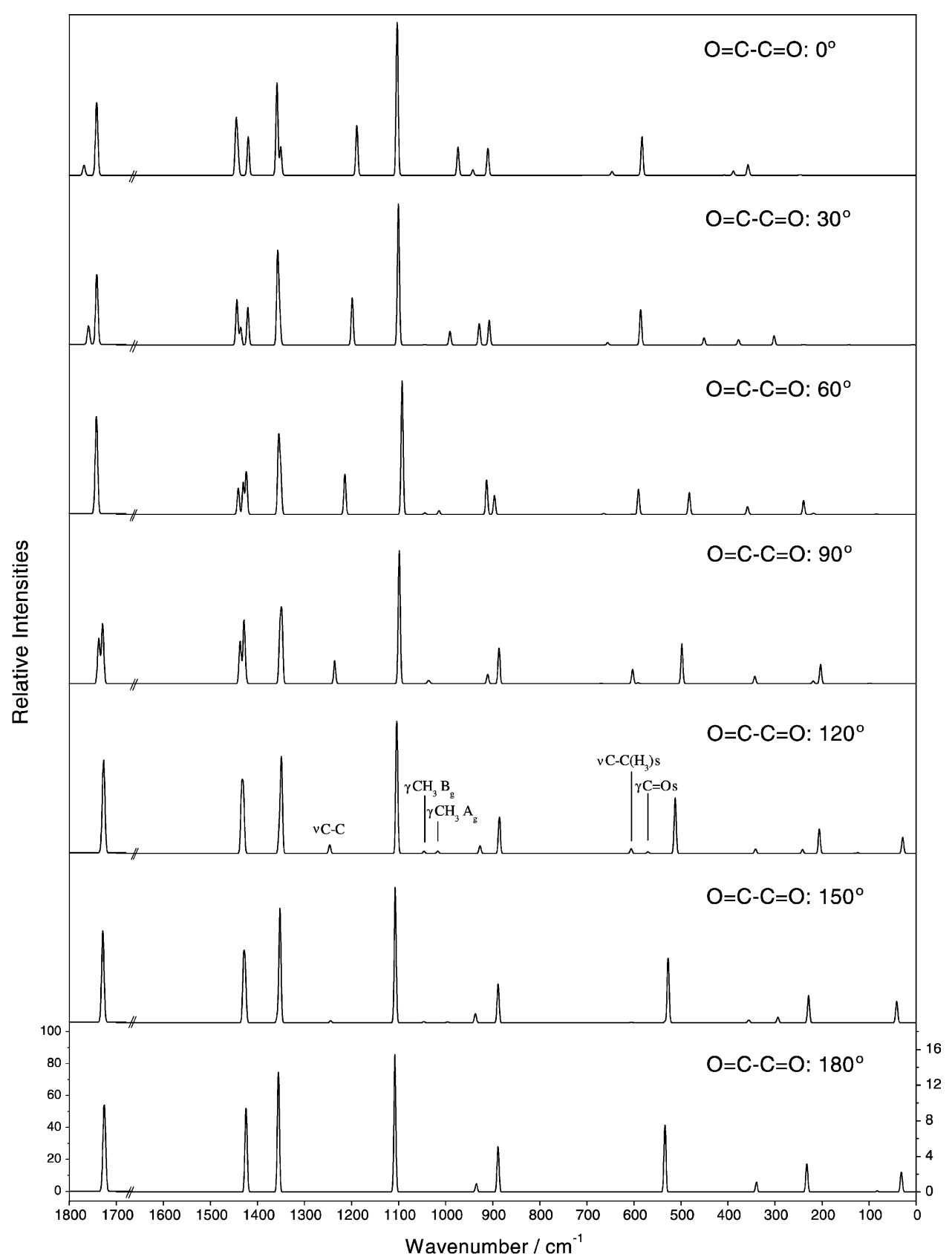

Fig. 4. $\mathrm{DFT}(\mathrm{B} 3 \mathrm{LYP}) / 6-311++\mathrm{G}(\mathrm{d}, \mathrm{p})$ calculated IR spectra as a function of the internal rotation around the $\mathrm{O}=\mathrm{C}-\mathrm{C}=\mathrm{O}$ dihedral angle.

phous diacetyl, we should be able to observe several 'new' bands in the spectrum even if only molecules with relatively small deviations from the trans conformation could be trapped in the glassy state. In addition, some of the IR active bands for the $C_{2 h}$ conformer should also shift in frequency in an observable way due to change of the $\mathrm{O}=\mathrm{C}-\mathrm{C}=\mathrm{O}$ dihedral angle. To have a more precise idea of the 
spectral changes that could be expected to occur due to the modulation of the vibrational spectra by the large amplitude low frequency $\tau \mathrm{C}-\mathrm{C}$ torsion, we adopted a classical model, based on the Boltzmann distribution of populations, to weight the relative contribution of each conformation differing in the $\mathrm{O}=\mathrm{C}-\mathrm{C}=\mathrm{O}$ dihedral angle to the physicochemical properties of diacetyl, within the range of tempera- tures of the vapour of the compound prior to deposition of the amorphous layer. Using the DFT(B3LYP)/6-311++G(d,p) calculated potential energy profile for internal rotation around the central $\mathrm{C}-\mathrm{C}$ bond (Fig. 5) and the approximation above, it can be easily calculated that conformations within $\pm 60^{\circ}$ from the trans structure should contribute to more than $95 \%$ to the total conformational population
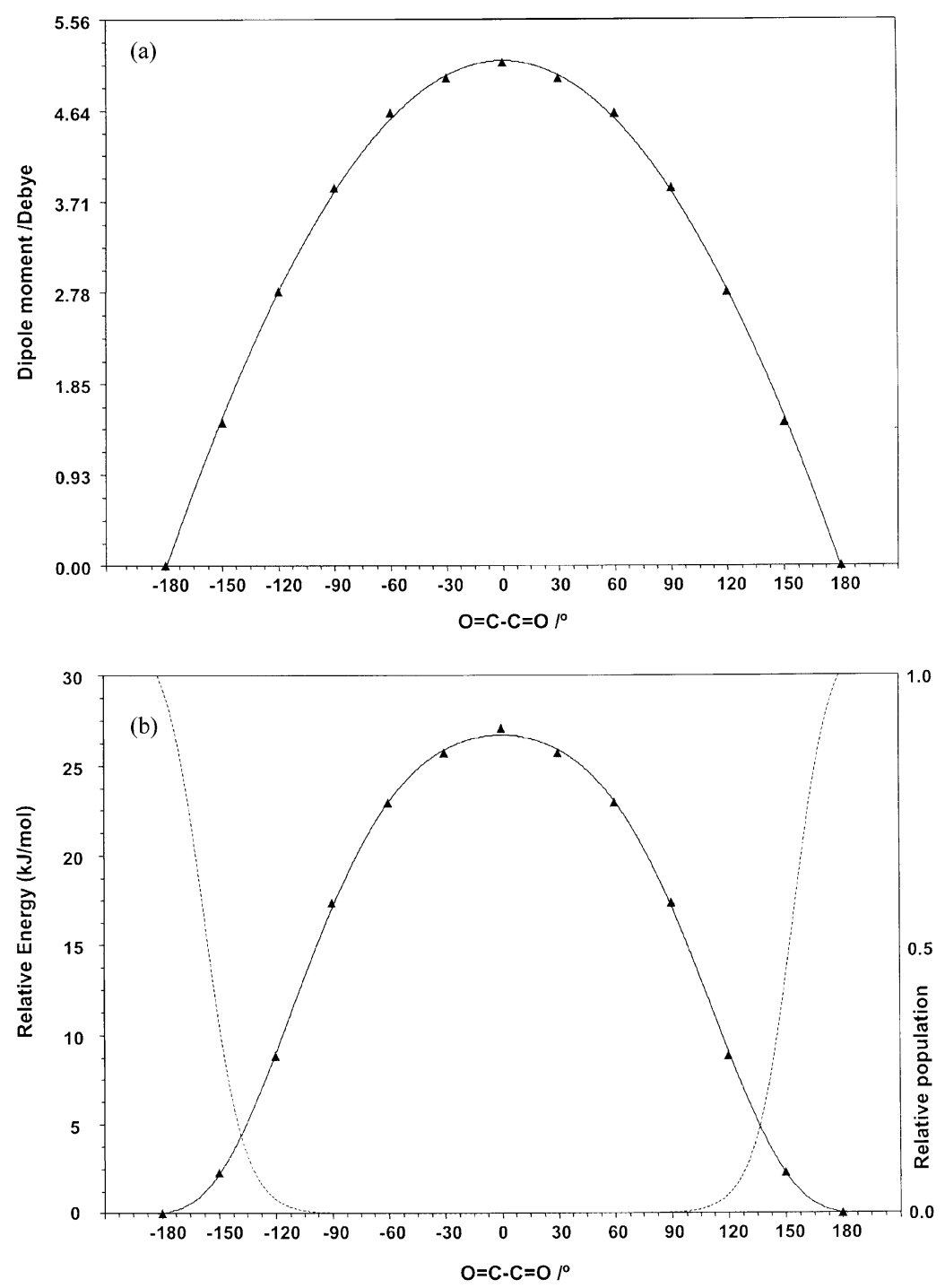

Fig. 5. (a). DFT(B3LYP)/6-311+ $+\mathrm{G}(\mathrm{d}, \mathrm{p})$ calculated dipole moment as a function of the $\mathrm{O}=\mathrm{C}-\mathrm{C}=\mathrm{O}$ dihedral angle. (b). DFT(B3LYP)/6$311++\mathrm{G}(\mathrm{d}, \mathrm{p})$ calculated relative energies $(-\boldsymbol{\Lambda}-)$ and energy-weighted relative populations for each conformation (obtained using a classical treatment of the distribution of molecules in various configurations and the Boltzmann distribution for $T=328 \mathrm{~K})(-$ - - - ). 
of diacetyl at room temperature. Hence, the observed spectrum of the amorphous layer can be interpreted as resulting from a sum of the energy-weighted spectra of all possible conformations having the $\mathrm{O}=\mathrm{C}-\mathrm{C}=\mathrm{O}$ dihedral angle within the $\left[-120^{\circ},+120^{\circ}\right]$ range. Taking this result into consideration, it is obvious from Fig. 4 that new low intensity bands corresponding to $\nu \mathrm{C}-\mathrm{C}$ (calculated frequency for the trans conformation: $\left.1244 \mathrm{~cm}^{-1}\right), \gamma \mathrm{CH}_{3} \mathrm{~B}_{\mathrm{g}}\left(1042 \mathrm{~cm}^{-1}\right)$, $\gamma \mathrm{CH}_{3} \mathrm{~A}_{\mathrm{g}}\left(989 \mathrm{~cm}^{-1}\right), \nu \mathrm{C}-\mathrm{C}\left(\mathrm{H}_{3}\right) \mathrm{s}\left(667 \mathrm{~cm}^{-1}\right)$ and $\gamma \mathrm{C}=\mathrm{O} \mathrm{s}\left(603 \mathrm{~cm}^{-1}\right)$ should be observed experimentally in the spectral region investigation in this study. Accordingly, bands were observed experimentally at $1234,1047,1002,693$ and $614 \mathrm{~cm}^{-1}$, respectively.

The observed frequency shifts of the peaks corresponding to the IR active bands in the trans conformation (comparing the IR spectra of the amorphous and crystalline samples) further reinforce the above interpretation, since they systematically occur in the direction predicted by the calculations if we assume the additional contribution of non-trans conformations to the IR spectrum of the amorphous phase. This is clearly noticed, for example, in the cases of $\gamma \mathrm{CH}_{3} \mathrm{~B}_{\mathrm{u}}$ (which shifts from $1126 \mathrm{~cm}^{-1}$ in the crystal to $1123 \mathrm{~cm}^{-1}$ in the glassy state), $\gamma \mathrm{CH}_{3} \mathrm{~A}_{\mathrm{u}}$ (from $957 / 951$ to $949 \mathrm{~cm}^{-1}$ ), $\nu \mathrm{C}-\mathrm{C}\left(\mathrm{H}_{3}\right) \mathrm{s}$ (from 914 to $912 \mathrm{~cm}^{-1}$ ) and $\delta \mathrm{C}=\mathrm{O}$ as (from 546/544 to $543 \mathrm{~cm}^{-1}$ ), that were all predicted to decrease in frequency for conformations progressively deviated from the trans form (within the relevant $\left[-120^{\circ},+120^{\circ}\right]$ range of variation of the $\mathrm{O}=\mathrm{C}-\mathrm{C}=\mathrm{O}$ dihedral angle). One apparent exception to this rule is the carbonyl stretching vibration, which is predicted to slightly reduce its frequency in going from the crystal to the amorphous state, but in fact increases from $1719 / 1711$ to $1725 / 1715 \mathrm{~cm}^{-1}$. However, this might be easily explained taking into account the effects of inter molecular interactions: being an organized structure, the crystal maximizes the stabilizing electrostatic intermolecular interactions, which in diacetyl involve mainly the carbonyl fragments, leading to more polarized $\mathrm{C}=\mathrm{O}$ bonds and then reducing their double bond character and thus, their frequency, relatively to the essentially disordered amorphous state.

The trends now discussed for the amorphous state can be extended to the liquid phase, where bands due to the non IR active in the trans conformation are also observed experimentally and, as expected, generally increase of intensity with the temperature (see Table 3, for band assignments).

Comparing now the results obtained for the matrix isolated compound and the amorphous state, one can extracted important information regarding the mechanisms associated with the relaxation of molecular conformation towards the minimum energy trans structure. The first piece of information is that, contrarily to what succeeds in the glassy state, only molecules assuming the trans $C_{2 h}$ geometry exist in the matrix. Since both samples were prepared from the vapour of the compound initially kept at the same temperature, the origin of the different observed behaviour must be attributed to the properties of the environment at the molecule arriving point, in particular: (1) local temperature, which shall also depend of the gaseous fluxes used during deposition, (2) local order and packing, and (3) local electric field. The local temperature can be expected to be higher in the case of the deposition of the matrix, since besides the flux due to the vapour of diacetyl simultaneous deposition of the matrix gas (argon) occurs. Hence, the available thermal energy makes easier any favourable conformational rearrangement, even in the case it would require a certain rearrangement of the atoms of the host as well. The local order is also higher in the case of the matrix experiment, as they are the packing requirements, since the arriving molecule faces an essentially crystalline media (argon crystal), while in the case of deposition of the amorphous layer it faces an essentially disordered molecular environment. It is well known that in general more planar structures are stabilized in matrices $[43,44]$. On the other hand, the local electric field is considerably more important for the amorphous layer. Electrostatic interactions shall then stabilize conformations with higher values of the dipole moment, which for diacetyl correspond to structures with a smaller $\mathrm{O}=\mathrm{C}-\mathrm{C}=\mathrm{O}$ dihedral angle (see Fig. 5). So, all these factors favour the presence of non-trans diacetyl molecules in the amorphous layer and their absence in the matrices, as experimentally found.

The importance of the large amplitude low frequency torsional vibration around the central $\mathrm{C}-\mathrm{C}$ bond to determine the physicochemical properties of diacetyl in the liquid and gaseous phases 
can also be used to solve the apparent inconsistency of previous spectroscopic studies (which claim exclusive contribution of trans molecules to the observed spectra [21-25]) and dipole moment measurements in these phases (which show that dipole moment is not zero, but ca.1 Debye [29]). Indeed, a rough estimation of the average dipole moment resulting from the energy-weighted dipole moments of all significantly populated (according to the Boltzmann distribution) conformations of diacetyl can be obtained from Eq. (1)

$\mu=\int_{0}^{2 \pi} \mu(\alpha) N(\alpha) \mathrm{d} \alpha$

where $\alpha$ is the $\mathrm{O}=\mathrm{C}-\mathrm{C}=\mathrm{O}$ dihedral angle and $N(\alpha)$ is the fractional population corresponding to the $\alpha$ value of $\mathrm{O}=\mathrm{C}-\mathrm{C}=\mathrm{O}$, which is given by

$N(\alpha)=\frac{\mathrm{e}^{\frac{-E(\alpha)}{\mathrm{RT}}}}{\int_{0}^{2 \pi} \mathrm{e}^{\frac{-E(\alpha)}{\mathrm{RT}}} \mathrm{d} \alpha}$

In Fig. 5 the dipole moment (calculated at the DFT(B3LYP)/6-311++G(d,p) level of theory) is plotted as a function of $\alpha$. Note that for all conformations the two acetyl groups are equivalent by symmetry and related to each other by a rotation around a $C_{2}$ axis (all conformations are $C_{2}$ except the planar trans and cis forms, which are $C_{2 h}$ and $C_{2 v}$, respectively); in all cases the dipole moment is aligned with the $C_{2}$ axis of the molecule and points into the same direction, thus very conveniently reducing the problem to one dimension.

Eq. (1) was integrated numerically using the relative energies and dipole moments calculated at the DFT(B3LYP)/6-311++G(d,p) for five different temperatures $(328,361,398,437$ and $478 \mathrm{~K})$. The results are shown in Table 4, together with the available experimental dipole moments measured at the same temperatures [29]. As it can be noticed, the predicted dipole moments agree satisfactorily with the experimental data. Noticeably, the dependence of the dipole moment with temperature obtained experimentally is very well fitted by the calculations. The fact that the predicted dipole moments are systematically smaller (ca. 15\%) than the experimental values may indicate that the DFT calculations slightly underestimated the dipole moments (in a recent study, DFT(B3LYP)/6-311++G(d,p)
Table 4

Experimental $\left(\mu_{\text {exp }}\right)$ [29] and calculated ( $\left.\mu_{\text {calc }}\right)$ dipole moment of diacetyl and absolute value of the estimated average deviation of the $\mathrm{O}=\mathrm{C}-\mathrm{C}=\mathrm{O}$ dihedral angle from $180^{\circ}$ as a function of the temperature

\begin{tabular}{llll}
\hline Temperature/K & $\mu_{\text {exp }} /$ Debye & $\mu_{\text {calc }} /$ Debye & $|\Delta \alpha|^{\text {a }}$ \\
\hline 328 & 1.05 & 0.88 & 18.8 \\
362 & 1.11 & 0.95 & 19.6 \\
398 & 1.16 & 0.99 & 20.5 \\
438 & 1.22 & 1.03 & 21.4 \\
478 & 1.27 & 1.07 & 22.1 \\
\hline
\end{tabular}

a $\Delta \alpha=\left(180^{\circ}-\alpha\right)$, with $\alpha$ being the $\mathrm{O}=\mathrm{C}-\mathrm{C}=\mathrm{O}$ dihedral

calculations were also found to slightly underestimate the dipole moments of the two conformers of acetaldoxime [45]). However, the possibility of a systematic error in the experimental values cannot be ruled out, since the authors of the experimental work mentioned that they encountered some difficulty in purification of their sample and suggest rechecking of the reported values in a further experiment [29].

We can also use a modification of Eq. (1) to estimate the energy-averaged value for the absolute deviation of the $\mathrm{O}=\mathrm{C}-\mathrm{C}=\mathrm{O}$ angle from $180^{\circ}$ at a given temperature. To do this, it is enough substituting in (1) the dipole moment function, $\mu(\alpha)$, by $|\Delta \alpha|$, where $\Delta \alpha=\alpha-180^{\circ}$. The results are also shown in Table 4 , for several temperatures, and indicate that within the $300-500 \mathrm{~K}$ interval $|\Delta \alpha|$ is around $20^{\circ}$, a result that is also consistent with a dipole moment for diacetyl of ca. 1 Debye (see Fig. 5; interpolation of the dipole moment function for $\mathrm{O}=\mathrm{C}-\mathrm{C}=\mathrm{O}$ equal to $160^{\circ}$ yields $\mu=1.03 \mathrm{D})$.

\section{Conclusion}

Matrix-isolation and low temperature solid state FT-IR spectroscopic studies on 2,3-butanedione (diacetyl), supported by molecular orbital calculations undertaken at the DFT(B3LYP) and MP2 levels of theory, enabled to conclude that in the crystalline phase and in low temperature inert gas matrices the compound exists in the $C_{2 h}$ symmetry, trans conformation $\left(\mathrm{O}=\mathrm{C}-\mathrm{C}=\mathrm{O}\right.$ dihedral angle of $\left.180^{\circ}\right)$. On the other hand, in the low temperature amorphous state, obtained by fast deposition of the vapour of the compound onto a suitable cold $(9 \mathrm{~K})$ substrate, as 
well as in the liquid and gaseous phases, molecular conformations without an inversion centre $\left(C_{2}\right.$ symmetry) were also shown to be important in determining physicochemical properties of diacetyl, such as vibrational spectra and dipole moment. These conformations were shown to become important as a consequence of the low frequency large amplitude torsional vibration around the central $\mathrm{C}-\mathrm{C}$ bond, which significantly distorts the molecular geometry from the $C_{2 h}$ symmetry minimum energy conformation. Taking into consideration the effects of the $\tau \mathrm{C}-\mathrm{C}$ torsional vibration, and using a simple classical model in which the molecular properties were energy averaged according to the Boltzmann distribution, a permanent dipole moment of ca.1 Debye was predicted for diacetyl for temperatures in the range $300-500 \mathrm{~K}$, in good agreement with experimental data [29]. Besides a precise vibrational and structural characterization of diacetyl under several experimental conditions, the present study could also identify the key molecular property that enabled to conciliate the existence of a single minimum in the potential energy surface of diacetyl at the trans $C_{2 h}$ conformation (as predicted by theoretical methods [26-28]), with the observed non-zero dipole moment for the liquid and gaseous compound [29].

\section{Acknowledgements}

This work was supported by the Portuguese Fundação para a Ciência e a Tecnologia (Research Project POCTI/QUI/43366/2001 and Grant FCT \#SFRH/BPD/11499/2002).

\section{References}

[1] M.L. Escamilla-Hurtado, A. Tomasini-Campocosio, S. Valdes-Martinez, J. Soriano-Santos, Rev. Latinoam. Microbiol. 38 (1996) 129.

[2] M. Kleerebezem, I.C. Boels, M.N. Groot, I. Mierau, W. Sybesma, J. Hugenholtz, J. Biotechnol. 98 (2002) 199.

[3] D. Midje, E.D. Bastian, H.A. Morris, F.B. Martin, T Bridgeman, Z.M. Vickers, J. Agric. Food Chem. 48 (2000) 1630.

[4] J. Hugenholtz, M. Kleerebezem, Curr. Opin. Biotechnol. 10 (1999) 492.
[5] C. Monnet, F. Aymes, G. Corrieu, Appl. Environ. Microbiol. 66 (2000) 5518.

[6] K. Kreiss, A. Gomaa, G. Kullman, K. Fedan, E.J. Simoes, P.L. Enright, N. Engl. J. Med. 347 (2002) 330.

[7] A.F. Hubbs, L.A. Battelli, W.T. Goldsmith, D.W. Porter, D. Frazer, S. Friend, D. Schwegler-Berry, R.R. Mercer, J.S. Reynolds, A. Grote, V. Castranova, G. Kullman, J.S. Fedan, J. Dowdy, W.G. Jones, Toxicol. Appl. Pharmacol. 185 (2002) 128.

[8] G.M. McClelland, J.T. Yardley, J. Chem. Phys. 58 (1973) 4368.

[9] H. Chen-Liang, L. Hon-Huei, L. Chen-Lin, A.H. Kung, ChiKung N, J. Chem. Phys. 117 (2002) 5165.

[10] C. Yang, P. Linsen, J. Jin, Y. Gao, M. Xingxiao, C. Congxiang, Chem. Phys. Lett. 323 (2000) 125.

[11] D.C. Moule, A.C. Sharp, R.H. Judge, H. Liu, E.C. Lim, J. Chem. Phys. 108 (1998) 1874.

[12] A. Inoue, Chem. Phys. Lett. 132 (1986) 72.

[13] L.H. Spangler, D.W. Pratt, J. Chem. Phys. 84 (1986) 4789.

[14] T.K. Ha, Chem. Phys. Lett. 57 (1978) 64.

[15] Y. Hatano, S. Takao, T. Ueno, Chem. Phys. Lett. 30 (1975) 429.

[16] K. Eriks, T.D. Hayden, S. Hsi Yang, I.Y. Chan, J. Am. Chem. Soc. 105 (1983) 3940.

[17] K. Hagen, K. Hedberg, J. Am. Chem. Soc. 95 (1973) 8266.

[18] J.E. Lu Valle, V. Schomaker, J. Am. Chem. Soc. 61 (1939) 3520 .

[19] D. Danielson, K. Hedberg, J. Am. Chem. Soc. 101 (1979) 3730 .

[20] H. Cerfontain, C. Kruk, R. Rexwinkel, F. Stunnenberg, Can. J. Chem. 65 (1987) 2234.

[21] K. Noack, R.N. Jones, Z. Elektrochem. 64 (1960) 707.

[22] J.W. Sidman, D.S. Mc Clure, J. Am. Chem. Soc. 77 (1955) 6471.

[23] R.K. Harris, R.E. Witkowski, Spectrochim. Acta 20 (1964) 1651

[24] R. Sander, H. Bettermann, J. Mol. Struct. 263 (1991) 123.

[25] J.R. Durig, S.E. Hannum, S.C. Brown, J. Phys. Chem. 75 (1971) 1946.

[26] V.G. Smeyers, M.L. Senent, F.Y.J. Peñalver, D.C. Moule, J. Mol. Struct. (Theochem) 287 (1993) 117.

[27] J. Tyrrell, J. Mol. Struct. (Theochem) 258 (1992) 41.

[28] C. Van Alsenoy, V.J. Klimkowski, L. Schäfer, J. Mol. Struct. (Theochem) 109 (1984) 321.

[29] G.I.M. Bloom, L.E. Sutton, J. Chem. Soc. (1941) 727.

[30] M. Frisch, G. Trucks, H. Schlegel, G. Scuseria, M. Robb, J. Cheeseman, V. Zakrzewski, J. Montgomery, R. Stratmann, K, Burant, S. Dapprich, J. Millam, A. Daniels, K. Kudin, M. Strain, O. Farkas, J. Tomasi, V. Barone, M. Cossi, R. Cammi, B. Mennucci, C. Pomelli, C. Adamo, S. Clifford, J. Ochterski, G. Petersson, P. Ayala, Q. Cui, K. Morokuma, D. Malick, A. Rabuck, K. Raghavachari, J. Foresman, J. Cioslowski, J. Ortiz, A. Baboul, B. Stefanov, G. Liu, A. Liashenko, P. Piskorz, I. Komaromi, R. Gomperts, R. Martin, D. Fox, T. Keith, M. Al-Laham, C. Peng, A. Nanayakkara, M. Challacombe, P. Gill, B. Johnson W. Chen, M. Wong, J. Andres, C. Gonzalez, M. Head-Gordon, 
S. Replogle, J. Pople. 1998. Gaussian 98, revision A.9; Gaussian Inc.: Pittsburgh, PA.

[31] M.J. Frisch, M. Head-Gordon, J.A. Pople, Chem. Phys. Lett. 166 (1990) 281.

[32] A.D. Becke, Phys. Rev. A 38 (1988) 3098.

[33] C.T. Lee, W.T. Yang, R.G. Parr, Phys. Rev. B 37 (1988) 785.

[34] S.H. Vosko, L. Wilk, M Nusair, Can. J. Phys. 58 (1980) 1200.

[35] P. Csaszar, P. Pulay, J. Mol. Struct. (Theochem) 114 (1984) 31.

[36] J.H. Schachtschneider, Technical Report; Shell development Co. Emeryville, CA, 1969.

[37] A.E. Dorigo, D.W. Pratt, K.N. Houk, J. Am. Chem. Soc. 109 (1987) 6591.

[38] W.J. Tabor, J. Chem. Phys. 27 (1957) 274.
[39] R.F. Curl, V.M. Rao, K.V.L.N. Sastry, J.A. Hodgeson, J. Chem. Phys. 39 (1963) 3335.

[40] L. Pierce, C.K. Chang, M. Hayashi, R. Nelson, J. Mol. Spectrosc. 5 (1969) 449.

[41] A.M. Alsanoosi, A.J. Horsewill, Chem. Phys. 160 (1992) 25

[42] S.B. Lopes, L. Lapinski, R. Fausto, Phys. Chem. Chem. Phys. 4 (2002) 1014.

[43] I.D. Reva, S.V. Ilieva, R. Fausto, Phys. Chem. Chem. Phys. 3 (2001) 4235.

[44] I.D. Reva, S.G. Stepanian, L. Adamowicz, R. Fausto, Chem. Phys. Lett. 364 (2003) 371.

[45] A. Andrzejewska, L. Lapinski, I.D. Reva, R. Fausto, Phys. Chem. Chem. Phys. 4 (2002) 3289. 